\title{
A Panoramic Review of the State Practice Section in the Asian Yearbook of International Law
}

\author{
Seryon Lee*
}

The purpose of this article is to provide an overview of the State Practice section in the Asian Yearbook of International Law from Vol. 1 to Vol. 24 on the occasion of the 25th anniversary issue of the Asian Yearbook of International Law. For the past 24 volumes, state practice rapporteurs from 16 Asian countries ${ }^{1}$ have reported various sources of state practice such as legislation, judicial decisions, government statements made at the United Nations and international conferences. As was evident from the voluminous record, the State Practice section from the past volumes covered topics ranging from state immunity, extradition, law of the sea, international human rights, relationship between international law and domestic law, territorial disputes among others. This collection of state reports revealed continuous efforts from Asian countries to enact the necessary legislation to give domestic effect to international treaties to which they assumed an obligation. Such efforts to abide by international obligation were also reflected in a number of court cases by referring to relevant international instruments. One notable point about the state practice of Asian countries is that there were relatively few cases of international adjudication among Asian countries. It can be inferred from such a finding that governments of Asian countries have preferred diplomacy over legal adjudication as a way of dispute settlement when faced with a conflict or dispute with other countries. The collection of state report from Asian countries over the three decades have undoubtedly contributed to the development of international law as such evidence of state practice forms an essential part of customary international law.

The following summaries have been arranged by country. While distinction between public international law and private international law has become more obscure in recent years, this article sought to confine the subject matter primarily related to public international law. In each summary, the contents are summarized mostly in chronological order, and some summaries, where appropriate, are arranged by different sources of state practice.

* Professor, Jeonbuk National University, Korea.

1 Bangladesh, China, India, Indonesia, Iran, Japan, Korea, Malaysia, Nepal, Pakistan, the Philippines, Singapore, Sri Lanka, Tajikistan, Thailand, Vietnam (in alphabetical order). 


\section{State Practice of Asian Countries}

\subsection{Bangladesh}

Bangladesh's state practice report first appeared in Vol. 10 with introduction of the enactment of the Arbitration Act of 2001. This Act repealed the Arbitration Act of 1937 and 1940, which were legacies of the British Raj in India. This legislative step was taken in response to increasing foreign investment in Bangladesh in various sectors, especially in natural gas and power, and export trade. ${ }^{2}$

In Vol. 16 (2010), the Supreme Court's case, State v. Secretary, Ministry of Law, Justice \& Parliamentary Affairs and others, decided on April 10, 2009, concerned the content of a TV news broadcast featuring the rape of a minor girl. The Court, particularly drew upon the comments of the UN Convention on the Rights of the Child (CRC) Committee on Bangladesh State Report and quoted observations and recommendations by the Committee. As part of the rulings, the Court provided a number of direction and recommendations, which included, among others, establishment of child-specific courts in every district to exclusively deal with cases relating to children. ${ }^{3}$

In 2012, Bangladesh enacted national laws related to human rights. On February 2O, 2012, Bangladesh Parliament enacted the Prevention and Suppression of Human Trafficking Act to provide for a legal regime to combat human trafficking effectively, whether internal or cross-border as well as to protect trafficking victims. The legislation of this Act was an attempt to enact anti-trafficking provisions at par with the United Nations Protocol to Prevent, Suppress and Punish Trafficking in Persons, Especially Women and Children 2000 (Palermo Protocol), even though Bangladesh has not ratified the Protocol. ${ }^{4}$ In the same year, Bangladesh also enacted the Pornography Control Act of 2012, which includes standards provided in the Optional Protocol to the Convention on the Rights of the Child on the Sale of Children, Child Prostitution and Child Pornography, 2000. ${ }^{5}$ Another important environmental law was enacted in 2012. The Wildlife Conservation and Security Act came into force on July 10, 2012. While there is no clear reference to specific international instruments, this Act seemed to incorporate provisions of the Convention on International Trade in Endangered Species of Wild Fauna and Flora (CITES),

2 Asian Yearbook of International Law, Vol. 10 (2001-2002), p. 167.

3 Asian Yearbook of International Law, Vol. 16 (2010), p. 207.

4 Asian Yearbook of International Law, Vol. 18 (2012), 25 o.

5 Asian Yearbook of International Law, Vol. 18 (2012), p. 157. 
the Convention on the Conservation of Migratory Species of Wild Animals, and the Convention on Biological Diversity. ${ }^{6}$

In the following year, the government of Bangladesh adopted the National Strategy Paper on Myanmar Refugees and Undocumented Myanmar National in order to address the situation of not only the registered refugees, but also the undocumented Myanmar nationals living in Bangladesh as part of a long-term solution to tackle the issue of the presence of a large number of undocumented Myanmar nationals. ${ }^{7}$

In Vol. 21, the Supreme Court's case in Salahuddin Qader Chowdhury v. The Chief Prosecutor (July 29, 2015), international crimes were discussed. In this case, the appellant was convicted by the International Crimes Tribunal on charges of crimes against humanity and war crimes committed during the Bangladesh war of liberation in 1971. The verdict of the Court touched upon the very core principles of international humanitarian laws as well as international human rights pertaining to prohibition of torture and non-discrimination based on religion. ${ }^{8}$

In recent volumes of 23 and 24, the Child Marriage Restraint Act of 2017 and the Digital Security Act of 2018 were introduced respectively. ${ }^{9}$ The Child Marriage Restraint Act included special circumstances where a boy or a girl can marry before they reach the statutory age in the best interests of the minor. The latter Act concerned the measures to deal with defamation, hurting religious sentiments, causing deterioration of law and order. This Act includes extraterritorial clause which means that Bangladesh nationals would be liable for punishment even if the offense was committed outside Bangladesh. ${ }^{10}$

\subsection{China}

China's state practice report starts with introduction of legislation of the Law on the Territorial Sea and Contiguous Zone, which was adopted on February 25, 1992..$^{11}$ On May 14, 2004, the Constitution of the People's Republic of China was amended to incorporate a human rights clause in Article 33, paragraph 3 , which states that "the state respects and protect human rights."12

\footnotetext{
$6 \quad$ Ibid, p. 166.

7 Asian Yearbook of International Law, Vol. 19 (2013), p. 207.

8 Asian Yearbook of International Law, Vol. 21 (2015), pp. 267-268.

$9 \quad$ Asian Yearbook of International Law, Vol. 23 (2017), p. 218; Vol. 24 (2018), p. 359.

10 Id.

11 Asian Yearbook of International Law, Vol. 2 (1992), p. 165.

12 Asian Yearbook of International Law, Vol. 11 (2003-2004), p. 151.
} 
Three extradition cases were presented in Vol. 11 (2003-2004) and Vol. 14 (2008) as follows:

First, the Supreme People's Court's decision on November 14, 2002 involved a French national who was suspected of committing a rape. The Supreme Court held that France duly provided evidence and materials as required by China's Extradition Law. The appellant's claim of the possibility of cruel treatment after returning to France was not accepted. The Supreme Court upheld the ruling by the High Court of Yunnan, which found that the request of France for extradition of the suspect fulfilled the conditions for extradition. ${ }^{13}$

Second, the Supreme People's Court decided another extradition case on April 2, 2007. This case concerned the request of extradition of a Korean citizen who was detained for committing a crime of fraud in China. He was convicted of fraud and sentenced to a sixteen-yar imprisonment by the Central District Court in Seoul, Korea. During the appeal proceeding, he fled to China. The High Court in Seoul affirmed the lower court's decision. The Supreme People's Court of China found that the crime committed constitutes crimes both under China's Criminal Law and Korea's Criminal Code. The Supreme Court held that the request for extradition met the conditions set forth in China's Extradition Law and the Extradition Treaty between China and Korea. ${ }^{14}$

Third, another extradition case was decided by the Supreme Cout on December 11, 2008. In this case, Korea requested the extradition of a citizen of Yemen who was convicted for the crime of illegal trading of firearms in Korea. The person subject to extradition submitted a written request to complete the remainder his sentences in his home country. The Supreme Court, noting that the extradition request met the requirements set forth in relevant laws, allowed him to be extradited to Yemen.15

In terms of diplomatic relations \& dispute settlement issues, following statements were made: In 2011, the Ministry of Foreign Affairs made statements with regard to its relationship with Sudan, ${ }^{16}$ and the new Libyan government. On June 21, 2011, the Ministry officially recognized and announced the establishment of diplomatic relations between China and Sudan, and endorsed support for the Libyan National Transitional Council, the new Libyan government, on July 9, 2011. ${ }^{17}$ In 2012, a Chinese representative at the UN General Assembly made a statement and endorsed Palestine's membership in international

\footnotetext{
13 Id. at 149-151.

14 Asian Yearbook of International Law, Vol. 14 (2008), pp. 147-148.

15 Asian Yearbook of International Law, Vol. 15 (2009), pp. 235-236.

16 Asian Yearbook of International Law, Vol. 17 (2011), p. 199.

17 Id. at. 200.
} 
organizations including the United Nations, ${ }^{18}$ and Palestine's independence as a sovereign state. ${ }^{19}$

On February 19, 2013, the Embassy of the People's Republic of China in the Philippines presented its compliments to the Department of Foreign Affairs of the Philippines, referring to the latter's Note Verbale regarding initiation of arbitration on the South China Sea issues and stated that the Philippines failed to abide by the agreement between the two countries to resolve territorial and jurisdictional dispute by peaceful means. On August 1, 2013, China addressed a Note Verbal to the Permanent Court of Arbitration in which it reiterated its position that "it does not accept the arbitration initiated by the Philippines" and stated that it would not participate in the proceedings. ${ }^{20}$

\subsection{India}

India has provided the most comprehensive court cases in several volumes. Just to highlight a few, the court cases pertaining to international law covered the various topics on domestic implementation of international treaties, international human rights law and jurisdictional issues as follows:

On November 25, 1993, the Supreme Court rendered its judgment in Veb. Deutfracht Seereedrei Rostock (D.S.R. Lines) v. New Central Jute Mills Co.Ltd \& Another, where the plaintiff filed a suit claiming that the defendant, D.S.R Lines sold them damaged goods. In the original case, the defendant was a company established under the laws of West Germany and carried its business both in West Germany as well as in Calcutta, India. D.S.R Lines argued that it was an agent and/or instrumentality of the government of the German Democratic Republic so that it should be recognized as a sovereign state. According to the German Democratic Republic's Constitution, private ownership in ocean shipping and large industrial enterprises was prohibited. Also, India's Code of Civil Procedure of 1908 required the prior consent of the central government if a suit involves the doctrine of state immunity. The Court, thus, examined the contemporary relevance of the absolute state immunity doctrine, which has ramifications both for international law and Indian law. The Court noted that there was a growing trend towards a restrictive theory and a distinction between commercial and sovereign acts was to be determined in terms of the nature of the acts. The appeal was allowed and the suit was dismissed. ${ }^{21}$

\footnotetext{
$18 \quad I d$.

19 Asian Yearbook of International Law, Vol. 19 (2013), p. 232.

20 Asian Yearbook of International Law, Vol. 19 (2013), pp. 212-213.

21 Asian Yearbook of International Law, Vol. 5 (1995), pp. 234-235.
} 
In National Human Rights Commission v. State of Arunachal Pradesh \& Another, the Supreme Court delivered the judgment on January 1995. This case was brought to the Supreme Court through a class action by the National Human Rights Commission (NHRC) of India in the form of a writ petition under the Indian Constitution. A large number of Chakmas were displaced as a result of Kaptai Hydel Power Project in 1964, and they took shelter in the nearby Indian states. In 1994, a Chaka NGO filed a representation with NHRC complaining of the persecution of Chakmas. The Supreme Court allowed the NHRC petition and ordered that the State of Arunachal Pradesh shall protect "the life and liberty of every Chakma residing within the State" and shall repel, even by use of force, any attempt by any organized group to forcibly evict the Chakmas. The Court further held that except in accordance with law, the Chakmas should not be evicted from their residence. While the traditional rule of international law recognizes the sovereign right of a state to decide the maters on admitting a foreigner, the international law on human rights became part of the legal system of most civilized societies. The Court, by referring, in particular, to non-derogable clause in the International Covenant on Civil and Political Rights, noted that certain human rights are non-derogable in any circumstances. In this case, the Court endorsed the international human rights in so far as its application through the Indian law concerned. ${ }^{22}$

In Narmada Bachao Andolan v. Union of India and Others, the Supreme Court rendered its decision on October 18, 2000. One of the key issues was applicability of the ILO Convention 107 to which India is a signatory. This case involved construction of various hydropower and irrigation project, which resulted in the large-scale displacement of people, particularly the tribal villagers. The Court noted that the relevant provision in the ILO Convention which stipulates in relevant part that the removal of the tribal population is necessary as exceptional measures, and they should be properly compensated with the land of quality and any resulting loss. ${ }^{23}$

On February 14, 2003, the Supreme Court decided on the issue related to implementation of the United Nations Conventions on Privileges and Immunities through domestic legislation. The Appellant was an employee of the International Crops Research Institute (ICR ISAT), an international organization located in India and employment was terminated by the ICRISAT. The appellant invoked the writ jurisdiction of the High Court of Karnataka, but the High Court dismissed the case on the ground that ICRISAT was an international organization, which enjoyed immunity due to a Notification issued in

22 Asian Yearbook of International Law, Vol. 6 (1996), pp. 203-204.

23 Asian Yearbook of International Law, Vol. 10 (2001-2002), pp. 171-172. 
1972 under the United Nations Privileges and immunities Act. The enactment in 1947 provided for the implementation of the UN Convention on Privileges and Immunities. The UN Convention appeared as a Schedule in the 1947 legislation and the UN Convention was applied by India by issuing Notifications from time to time. The Court examined the legal character of ICRISAT and noted that the primary activity was purely on a voluntary basis. The Court also pointed out that the agreement between the Indian Government and ICRISAT is enforceable in domestic courts when the agreement does not form part of any domestic legislation. ${ }^{24}$

In the Republic of Italy \& Others $v$. Union of India \& Others, decided by the Supreme Court on January 18, 2013, the Italian ship while on its journey near the coast of the Indian States of Kerala, allegedly mistook an Indian fishing vessel for a pirate boat and fired gun shots at the fishing vessel resulting the death of two Indian fishermen. Two main issues were all related to jurisdiction matters. The first issue was whether the Kerala State Police had jurisdiction to investigate the incident. The second issue was whether the Courts of the Italy or India had jurisdiction to try the accused. Italy argued that its marines were on board in their official capacity. The Court considered the argument by Italy and pointed out that the incident happened within the Contiguous Zone and the Exclusive Economic Zone, which indicates that the incident occurred within the jurisdiction of one of the federal units of India. Accordingly the Court held that the State of Kerala had no jurisdiction, rather it was the Indian Government that had jurisdiction to proceed with the investigation and trial in accordance with the UN Convention on the Law of the Sea. The Supreme Court directed the Government of India to set up a Special Court in consultation with the Chief Justice of India to dispose of the case in accordance with the provisions of the UNCLOS along with relevant India's domestic laws. ${ }^{25}$

Volume 9 covered the ICJ's judgment on June 21, 2000, in the case concerning Aerial Incident of 10 August 1999 between Pakistan and India. India's preliminary objections concerned the so-called "commonwealth reservation" and reservation on multilateral convention, the General Act of 1928, which requires the consent of jurisdiction by the Indian government. The ICJ found that India had never been a party to the General Act as an independent state, however, even if the General Act bound India, the subsequent communication by India in 1974 served as the notification of denunciation of the Act. The ICJ found that it had no jurisdiction as contended by India. ${ }^{26}$

24 Asian Yearbook of International Law, Vol. 11 (2003-2004), pp. 16o-161.

25 Asian Yearbook of International Law, Vol. 19 (2013), pp. 340-345.

26 Asian Yearbook of International Law, Vol. 9 (2000), pp. 223-228. 
Volume 18 included a number of nationals laws, which were enacted to ratify international human rights treaties as follows: Act No. 6 of 2012 on ratification of International Convention on the Protection of the Rights of All Migrant Workers and Members of Their Families, Act No. 9 of 2012 on Ratification of Optional Protocol to the Convention on the Rights of the Child on the Involvement of the Children in Armed Conflict, Act No. 10 of 2012 on Ratification of the Optional Protocol on the Sale of Children, Child Prostitution and Child Pornography.

\section{$1.4 \quad$ Indonesia}

The state practice report of Indonesia first appeared in Volume 6 with the introduction of Indonesia's Act on Indonesian Waters on August 8, 1996..27 On June 28, 2002, the Government Regulation was issued on the Rights and Obligations of Foreign Ships and Aircraft when Exercising the Right of Archipelagic Sea Lanes Passage through Established Archipelagic Sea Lanes to implement the Law of 1996 concerning Indonesian Waters. ${ }^{28}$

The legislations related to diplomatic relations and human rights were also adopted between 1999 and 2000 as follows: The Act on Foreign Relations of 1999, Act on Human Rights of 1999, the Act on International Agreements of 2000 and the Act on the Court for Fundamental Rights of 2000. ${ }^{29}$

In response to the Bali Bombing on October 12, 2002, the President issued Government Regulation in lieu of Law No. 1 of 2002 (GRL) concerning the Eradication of Criminal Acts of Terrorism. The Government Regulation applied to any person who commits or intends to commit a criminal act of terrorism in the territory of Indonesia and/or other country that has jurisdiction and expresses its intention to prosecute such criminal. ${ }^{30}$

In 2014, Law No. 26 of 2014 on the Ratification of the ASEAN Agreement on Transboundary Haze Pollution and Law No. 1 of 2014 on the Accession to the International Convention for the Suppression of Acts of Nuclear Terrorism were enacted. ${ }^{31}$

A judicial decision regarding crime against humanity was discussed in Prosecutor Office of the Republic of Indonesia v. Abilio Jose Osario Soares, decided on April 4, 2002. The defendant was accused of crimes against humanity under the Indonesia's Law No. 26 of 200o. One of the main arguments by the defendant

\footnotetext{
27 Asian Yearbook of International Law, Vol. 6 (1996), p. 213.

28 Asian Yearbook of International Law, Vol. 10 (2001-2002), p. 187.

29 Asian Yearbook of International Law, Vol. 9 (2000), pp. 233-236.

30 Asian Yearbook of International Law, Vol. 10 (2001-2002), p. 181.

31 Asian Yearbook of International Law, Vol. 20 (2014), p. 281.
} 
was that the ad hoc Human Rights Court of the Central Jakarta Court did not have the jurisdiction to try his case since the alleged crime was not a criminal act at the time the incident happened. The Court, rejecting his argument, stated that crime against humanity constitutes an international crime so that the principle of universal jurisdiction applies. ${ }^{32}$

In Prosecutor Office of the Republic of Indonesia v. Timbul Silaen decided on March 28, 2002, the defendant was accused of crimes against humanity under the Law No. 26 of 200o. The defendant claimed that the ad hoc Human Rights Court of the Central Jakarta Court lacked the jurisdiction to try his case since the alleged crime occurred in East Timor. The Court rejected the defendant's claim and held that the principle of universal jurisdiction applies for the crime against humanity. ${ }^{33}$

\subsection{Iran}

Iran's first state practice report appeared in Volume 4 with introduction of the Act on the Marine Area of the Islamic Republic of Iran in the Persian Gulf and the Oman Sea. As Iran has not ratified the UN Convention on the Law of the Sea and the 1958 Geneva Convention, this newly enacted Act is significant to the extent that it consolidated all the laws on Iran's maritime zones and Iran's position as to the right of innocent passage. ${ }^{34}$

Iran's Single Act on Jurisdiction of Iranian Judiciary to Hear Civil Suits against Foreign States was enacted on November 9, 1999. This Act designated Tehran's Courts of Justice as competent organ to hear the proceedings instituted under this Act. Under this Act, Iranian nationals may bring civil action against foreign states for damaging arising from any act of a foreign state which is contrary to international law, and damages from any act of individuals or terrorist groups supported by a foreign State, resulting in death, physical, mental or financial injury to Iranian nationals. This Act applies to two categories of foreign states: (i) states that have violated sovereign immunity of Iran or immunity of its officials; (ii) states that have assisted in the execution of judgments that are made in violation of sovereign immunity of Iran or immunity of its officials. ${ }^{35}$

In Volume 11, the ICJ case concerning oil platforms between Iran and the United States, decided on November 6, 2003, was discussed in detail. This case concerned a dispute arising out of the attack on and destruction of three

\footnotetext{
32 Asian Yearbook of International Law, Vol. 10 (2001-2002), p. 18 o.

33 Id.

34 Asian Yearbook of International Law, Vol. 4 (1994), pp. 239-240.

35 Asian Yearbook of International Law, Vol. 9 (2000), p. 237.
} 
offshore oil production complexes by US warships. This case dealt a number of important issues such as use of force, meaning of armed attack to justify right of self-defence, legitimate military target, freedom of commerce and navigation. The Court found that the actions of the United States against Iranian oil platforms could not be justified as measures necessary to protect the essential security interests of the United States under the Treaty of Amity, Economic Relations and Consular Rights between the US and Iran. The Court also rejected Iran's contention that the action by the US constituted a breach of the obligation regarding freedom of commerce between the two parties. ${ }^{36}$

In the same volume, a case decided by Branch 213 of Tehran court in November, 2002 was discussed regarding domestic implementation of international treaties in Iran. This case concerned the expropriation of a vessel by a UAE court pursuant to the UN Security Council resolutions relating to the Iraqi oil embargos and the subsequent transfer of its ownership to an Iranian party. The Court held that the obligations arising from binding resolutions of the Security Council of the United Nations constituted binding international obligations applicable in the judicial proceedings before Iranian courts. Accordingly, it affirmed that the seizure and confiscation was made in accordance with the UN Charter and should, therefore, be respected by an Iranian court. ${ }^{37}$

\subsection{Japan}

A number of important court cases were introduced in the volumes published in the 199os, starting with an extradition case involving hijacking of an airplane of China Airlines on December 16, 1989. The hijacked airplane landed at Fukuoka in Japan, where the hijacker asked for political asylum. The Chinese government issued a warrant for arrest and requested extradition. The Tokyo High Court held that the requested person could be extradited as the hijacking could not be regarded as a political crime within the meaning of Japan's Law on Extradition of Criminal Offenders. ${ }^{38}$

Tokyo High Court's decision on March 5, 1993 concerned compensation for Japanese prisoners of war detained in the UsSR after World War. Former Japanese Pows and their surviving family instituted a lawsuit against Japan for settlement of the credit balances as well as for compensation for the injuries caused by the forced labor during the detention in the UssR. The Court examined two main issues related to international law. First, regarding the

36 Asian Yearbook of International Law, Vol. 11 (2003-2004), pp. 180-181.

37 Asian Yearbook of International Law, Vol. 11 (2003-2004), p. 182.

$3^{8}$ Asian Yearbook of International Law, Vol. 1 (1991), pp. 159-16o. 
applicability of the third Geneva Convention of 1949, the Court held that the Convention was not applicable because most of the plaintiffs lost their Pow status by repatriation before the Convention had entered into force between Japan and USSR. As to the claims by the plaintiffs on applicability of the socalled "Rule of compensation by the state on which the pow depends," as provided in Articles 66 and 68 of the third Geneva Convention, the Court did not recognize such provisions as an established rule of international customary law in the absence of evidence of general state practice and opinion juris. Second, while duly promulgated treaties and international customary law are recognized to have domestic effect without any special legislative acts in Japan, the content of a treaty or a international customary law at issue was not clear and precise in terms of the scope of entitled persons, methods or duration of the compensation. Therefore, the rule in question could not be applied domestically. Accordingly, the Tokyo High Court dismissed the appeal. ${ }^{39}$

This High Court's decision was affirmed by the Supreme Court on March 13, 1997. The Supreme Court upheld the judgment of the High Court without further consideration to the effect that the Geneva Convention cannot be applied retroactively to the claims of the appellants whose Pow status was terminated before the entry into force of the Convention between Japan and the Soviet Union. The Supreme Court confirmed that Rules of compensation by the state on which the Pow depends was not an established international customary law at the time when the appellants were detained in the USSR. ${ }^{40}$

Apart from the above Supreme Court's decision, Japan enacted the Law on the Punishment of the Grave Violations of International Humanitarian Law, which entered into force on February 28, 2005. As to the four Geneva Conventions of 1949, while Japan acceded to them in 1953, there was no legislation to bring them into effect. An additional clause to the Penal Code was amended and extended the application of the provision of Article 4 bis to the crimes to be punished under the Geneva Conventions even when they were committed outside Japan. ${ }^{41}$

Another Supreme Court case related to the aftermath of war, decided on April 5, 2001, concerned the Korean appellants who were severely wounded when they served as soldiers or paramilitary personnel in the Japanese military during World War II. In Seok Seong Gi and Successors of late Jin Seok IL v. The Minister of Health and Labour, the appellants claimed for the cancellation of the decision by the Japan's Minister of Health to reject their application for a

39 Asian Yearbook of International Law, Vol. 6 (1996), pp. $245^{-252 .}$

$40 \quad$ Asian Yearbook of International Law, Vol. 7 (1997), p. 287.

41 Asian Yearbook of International Law, Vol. 12 (2005-2006), p. 177. 
disability pension under the relevant Japanese Act. The Supreme Court pointed out that Peace Treaty with Japan identified claims by Koreans as the subject for special arrangements between Japan and Korea (Article 4(a)) and compensation was to be settled by diplomatic negotiations. The Court noted that both governments considered that compensation to Korean residents in Japan was a matter of the other government's responsibility under "The Agreement on the Settlement of the Problems concerning Properties and Claims, and the Economic Cooperation between Japan and Korea" concluded in 1965. For this reason, while the Court recognized a discriminatory treatment between the wounded Korean resident in Japan and those Japanese under similar circumstances, it denied the unconstitutionality of the situation. ${ }^{42}$

In Nishimatsu Construction Co. $v$. Y, the Supreme Court rendered its judgment on April 27, 2007. In this case, the appellant, Nishimatsu Construction, forced many Chinese people to work on the site of construction in Hiroshima Prefecture during the World War II. Former workers and their survivors claimed compensation for the forced labor and damages. The issue was whether the war reparation claims of Chinese citizens had been renounced by China. The Joint Communique between Japan and China in 1972 did not extinguish the Japanese government's obligation to respond to the compensation claims of Chinese nationals. The Supreme Court held that the Joint Communique meant comprehensive renouncement of the war reparations by China, including compensation claims of its nationals. This was the first ever judgment of the Supreme Court on the issue of whether the war reparation claims of nationals were renounced by the waiver clause of the peace treaty their country concluded. ${ }^{43}$

Volume 20 included the ICJ's judgment of Whaling in the Antarctic (Australia v. Japan: New Zealand intervening). On March 31, 2014, the ICJ issued the judgment of Whaling in the Antarctic, and held that the JARPA II, Japanese Whale Research Program, was not justified as scientific research under the International Convention for the Regulation of Whaling (ICRW).

\subsection{Korea (The Republic of Korea)}

Korea's state practice was first featured in Volume 10. The Supreme Court's decision on October 22, 2001 in Arah Marine Co. v. Marine Jewelry concerned direct application of treaty. The contracting carrier concluded the transportation contract with passengers, senders or their representatives in accordance with the Warsaw Convention for the Unification of Certain Rules Relating to

42 Asian Yearbook of International Law, Vol. 11 (2003-2004), pp. 189-19o.

43 Asian Yearbook of International Law, Vol. 13 (2007), pp. 211-212. 
International Carriage by Air as amended at the Hague of 1955. (Amended Warsaw Convention) The Court found that the case at issue concerned the international air transportation under the amended Warsaw Convention, therefore it is correct that the amended Warsaw Convention is applicable to the contract between the plaintiff and the defendant. ${ }^{44}$

The Constitutional Court examined the characteristics of National Assembly's right to consent regarding treaties in its decision on July 26, 2007 (2006 HunRi8). This case concerned the so-called 'rice negotiation' with the wTO Members in order to extend the special and differential treatment, which allowed a waiver for rice tariff for Korea from 1994 to 2004. Accordingly, the Korean Government submitted a proposal along with documents for ratifying the revised tariff concession. The petitioners were the members of the National Assembly and they requested the government to include the agreement documents by introducing a bill for ratification. However, the government declined such request. The petitioners argued that by entering into an agreement without the consent of the National Assembly, the government violated the National Assembly's right to consent to the conclusion and ratification of treaties. Therefore, the Court was asked to interpret the meaning of the National Assembly's right to consent under the Constitution, however, one of the key issues in this case was whether the petitioners have capacity to request on behalf of the National Assembly. Since the Court found that members of the National Assembly had no legal standing as valid claimants, the court dismissed the case. ${ }^{45}$

Seoul High Court's decision on July 10, 2013 (2012Na44947), featured in Volume 19, was a follow-up on the Supreme Court's decision on May 24, 2012. The Plaintiffs were Korean victims who were forced to work at Nippon Iron Manufacture during the Japanese colonial period. The Plaintiffs filed a suit for compensation for the illegal act of "Sinil Iron Casting," previously called Nippon Iron Manufacture, in their assisting the Japanese government's policy of compulsory mobilization of manpower. The Court examined the following legal issues: 1) Whether the activity of the Nippon Iron Manufacturing falls under the illegal acts against humanity which directly relates to the illegal colonization of Korea and the fulfillment of aggressive war; (2) whether the defendant can avoid responsibility under the argument of denying the same identity with formal Nippon Iron Manufacture or using decisions that was litigated in Japan by some of the plaintiffs, some parts of Japanese legislation, the Agreement on Reparation between Korea and Japan, statute of limitations,

44 Asian Yearbook of International Law, Vol. 10 (2001-2002), p. 196.

45 Asian Yearbook of International Law, Vol. 14 (2008). 
and so forth, 3) the standard for calculating the amount of compensation the defendant should pay. The Court held that Nippon Iron Manufacture must pay 100,000,000 KRW to the plaintiffs because its forceful manpower draft without paying wages was an unlawful act. ${ }^{46}$

In the same year, Seoul High Court gave a decision on January 3, 2013 (2012To1) regarding the request for extradition. This case concerned the Japanese government's request for extradition of a Chinese national who protested against Japan for its lack of historical awareness by attempting arson on the Yasukuni Shrine in Japan. The Court examined the applicable law to determine whether Korea had an obligation to extradite him Japan, the standard to determine the definition of political crime, and lastly whether the term, 'political crimes' in Article 3 of the Criminal Extradition Treaty between Korea and Japan was relevant to this case. The Court held that non-extradition of a political offender was the established principle of international law and further pointed out that the term, political crime in the said Extradition Treaty should be interpreted as a concept which includes the relative political crime. Accordingly, the Court decided not to allow the extradition. ${ }^{47}$

In the most recently published volume, Korean Constitutional Court's decision on June 28, 2019 regarding conscientious objectors for military service drew much attention. The Court found that the categories of military service under the Military Service Act was non-conforming to the Constitution on the ground that the Military Service Act provided only 5 categories of military service and excluded any alternative service for conscientious objectors. ${ }^{48}$

In terms of legislation, the Refugee Act was enacted in 2012 and came into force in July, 2013. The enactment of the Refugee Act reflected the Korean government's efforts and commitment under international law and provided a critical momentum on its refugee policy from immigration control to more human rights-based approach. ${ }^{49}$ On March 3, 2016, North Korean Human Rights Act entered into force. The Purpose of this Act is to contribute to protect and promote human rights of North Koreans by pursuing the right to liberty and right to life prescribed in the Universal Declaration of Human Rights and other international human rights treaties.

46 Asian Yearbook of International Law, Vol. 19 (2013), pp. 237-241.

47 Asian Yearbook of International Law, Vol. 19 (2013), pp. 261-262.

48 Asian Yearbook of International Law, Vol. 24 (2018), p. 388.

49 Asian Yearbook of International Law, Vol. 20 (2014). 


\subsection{Malaysia}

Malaysia's state practice was presented in Vol. 1 by introducing MalaysiaThailand Joint Authority Act of 1990, which was enacted pursuant to the memorandum of understanding between the two countries on the establishment of a joint authority for the exploitation of the resources of the sea-bed in a defined area of the continental shelf of the two countries. ${ }^{50}$ In 2010, a new Wildlife Conservation Act was passed by the Malaysian parliament to adopt licensing/ permit requirements to hunt, take, keep, deal, carry on a taxidermy business, import and export any protected wildlife, as well as to collect bird's nest in Malaysia. ${ }^{51}$

For the volumes published in the 1990s, important judicial decisions were highlighted as follows: In Commonwealth of Australia v. Midford Sdn. Bhd. \& Anor, the appellant was the officer from the Australian Customs Service and Malaysia seized certain documents belonging to the respondent. The respondent requested for an order that the seized documents be returned and that the Commonwealth of Australia and their agents be restrained from conducting further illegal searches or seizures on the respondent's premises. As the High Court held that Australia was not entitled to absolute immunity from the jurisdiction of the Malaysian courts, the appellant made an appeal to the Supreme Court. The doctrine and practice of the sovereign immunity under international law was examined. The Supreme Court decided that the lower court's judgment based on the restrictive doctrine of sovereign immunity developed in the common law after 1956 should apply in Malaysia. However, the Court further examined and concluded that the action of the Commonwealth of Australia at issue was acta jure imperii so that the Commonwealth of Australia was entitled to full sovereign immunity. ${ }^{52}$

In MBF Capetal Berhad \& Another v. Dato'param Cumaraswami, the High Court in Kuala Lumpur gave its decision on June 28, 1997 regarding immunity of United Nations Special Rapporteur. The plaintiffs were public-listed and a licensed stock-broking companies, and they filed a suit for defamation against an advocate and solicitor of the High Court of Malaya who was also appointed as a UN Special Rapporteur. The action involved an article in a magazine which featured the words spoken by the defendant in direct quotes. The defendant argued that he was entitled to immunity from any legal process based on the Convention on the Privileges and Immunities of the United Nations of 1946. The court examined about the mandate of a Special Rapporteur and the term

50 Asian Yearbook of International Law, Vol. 1 (1991), p. 160.

$5^{1} \quad$ Asian Yearbook of International Law, Vol. 17 (2011), p. 203.

$5^{2}$ Asian Yearbook of International Law, Vol. 1 (1991), pp. 162-164. 
'expert on mission' in detail and decided that it had jurisdiction to hear the case and accordingly dismissed the application.

However, the appeal was made and the Court of Appeal delivered its judgment on October 20, 1997. The issues examined in the appeal included two questions: i) whether the judicial commissioner was entitled to deter the question of the defendant's immunity, ii) even if the commissioner was entitled to do so, whether she properly exercised such discretion. The Court of Appeal pointed out that it was not entirely beyond dispute whether the words complained of were published by the defendant in the exercise of his functions as Special Rapporteur. It stated that the question of the independence of the defendant in the exercise of his functions as a Special Rapporteur is a matter that must be addressed with reference to the terms of his mandate. In Conclusion, the Court of Appeal upheld the judgment made by the High Court and dismissed the appeal on the ground that the High Court's decision did not result in any injustice. ${ }^{53}$

This case was updated in Volume 9. The Malaysian government and the Untied Nations agreed to refer the matter of immunity to the International Court of Justice. The Malaysian government also agreed to comply with the ICJ's decision. In the case concerning "Difference Relating to Immunity from Legal Processes of a Special Rapporteur of the Commission on Human Rights," the ICJ decided in favour of Dato'Param Cumaraswamy and held that immunity was a preliminary issue to be determined before hearing can continue, and further found that the defendant did have immunity and that all actions against him should be stopped. ${ }^{54}$

In a more recent volume, in 2018 the High Court in Kuala Lumpur decided in Wang Bao'An \& Ors $v$ Malaysian Airline System Bhd and Other Cases, which was a suit brought by a group of defendants of those who perished on board Malaysian Airlines Flight MH 370 on March 8, 2014 against the Malaysian Airline System Bhd. Two questions were raised at the hearing. First, whether the Convention for the Unification of Certain Rules for International Carriage by Air 1999 (Montreal Convention) and the Convention for the Unification of Certain Rules relating to International Carriage by Air 1929 (Warsaw Convention) provided exclusive causes of action against a carrier, ousting all common law causes of action. Second, whether the cap on liability for a dependency claim imposed by Section 7 of the Civil Law Act 1956 applied in respect of a claim made under the Montreal Convention. The Court decided that the Montreal Convention provided an exclusive cause of action and ousted all

53 Asian Yearbook of International Law, Vol. 7 (1997), pp. 294-309.

54 Asian Yearbook of International Law, Vol. 9 (2000), pp. 246-247. 
common law causes of action against the carrier, and the similar principle applied with regards to the Warsaw Convention. ${ }^{55}$

\section{$1.9 \quad$ Nepal}

From Volume 9 and onwards, a number of court cases in Nepal related to interpretation of international treaties were presented. The Supreme Court's decision on November 11, 2000, in Javir Yasin v. HMG Ministry of Home and Others was introduced. In this case, the petitioner was denied citizenship by the District Administration Office in Kathmandu on the ground that his father was not a Nepalese citizen. The petition was based on the claim that the petitioner was entitled to the equal protection of the Constitution of Nepal as well as the Convention on Elimination of All Forms of Discriminating against Women (CEDAW) to which Nepal is a party. The Court rendered its decision solely on the ground of the Constitution and held that citizenship of Nepal requires that the father to be a citizen of Nepal. However, the Court did not examine the relationship between the CEDAW and laws of Nepal regarding citizenship issue. ${ }^{56}$

Another Supreme Court's case, decided on July 19, 2001, in Tilotam Poudyal v. HMG Ministry of Home and Others, dealt with the issue of registration for a NGO by minors. The petitioners were minors when they applied for registration of a Non-Governmental Organization to the District Administration Office, which then asked for instructions from the Ministry of Home regarding registration of an NGO where the applicants were minors. Referring to Nepal's Association Registration Act of 1978, which stipulates that only citizens were eligible for registering an NGO, the Home Ministry noted that the applicants had not attained the age for obtaining citizenship and that they were not allowed to register an NGO in their names. One of the legal questions raised in this case was whether the denial of registration of a NGO to minor was inconsistent with the UN Convention on the Rights of Child. The Court held that the minors are citizens of Nepal, and Association Registration Act cannot preempt the fundamental rights guaranteed under the Constitution. It further noted that the UN Convention on the Rights of the Child prevailed over conflicting domestic laws. For these reasons, the Court ordered the Ministry to register the proposed application of an NGO. ${ }^{57}$

In the same year, the Supreme Court delivered its judgment in June 2001 on the Right to Clean Drinking Water in light of the wHo Standards. In Advocate

55 Asian Yearbook of International Law, Vol. 24 (2018), p. 393.

56 Asian Yearbook of International Law, Vol. 9 (2000), pp. 249-250.

57 Asian Yearbook of International Law, Vol. 10 (2001-2002), pp. 205-207. 
Prakash Mani Sharma v. Drinking Water Corporation, the petitioner asked the Court to issue a Writ of Mandamus against the respondent, Nepal Drinking Water Corporation, to provide clean drinking water to the consumers. The petitioner claimed that the standards of drinking water provided by Nepal Drinking Water Corporation was below the standards given by World Health Organization. One of the issues considered by the Court was whether the wHO Standards apply as mandatory rules. The Court did not specifically examine the legal validity of the wHo Rules, but stated that the Drinking Water Corporation was an autonomous body that was not required to receive directions from anyone..$^{58}$

In 2004, the Supreme Court reviewed the applicability of international humanitarian law and scope of the Geneva Convention of 1949 in Advocate Rajaram Dhakal and Others v. RT. Hon. Prime Minister and Others, and gave its decision on January 9, 2004. The petitioners asked the Court to issue an order or mandamus and/or a certiorari to give effect to the Geneva Convention, claiming that armed conflict between the Maoist and the State had escalated and resulted in casualties of civilians. Nepal ratified the Geneva Convention, but had done nothing to give effect to the Geneva Convention. Pursuant to Nepal's Treaty Act of 1991, the government was responsible for developing necessary mechanism to effectuate international law. The Court found that the situation raised by the petitioners did not involve a war between High Contracting Parties, which triggers international humanitarian law. However, it ordered the government to undertake its responsibility for enacting necessary legislation to provide sanctions for those who committed grave breaches of the Convention. ${ }^{59}$

In most recent Volume, a number of legislations related to human rights were noted as follows: Privacy Act, 2018, Public Health Service Act, 2018, The Right to Employment Act, 2018, Right to Food and Food Sovereignty Act, 2018, Right to Safe Motherhood and Reproductive Health Act, 2018, Social Security Act, 2018, Act Relating to Children, 2018, Act Relating to Compulsory and Free Education, 2018. ${ }^{60}$

\subsection{Pakistan}

Pakistan's court case was first presented in Vol. 3 with its Karachi High Court's decision on September 9, 1992. In Messar Najib Zarab limited v. Government of Pakistan through the Secretary, Ministry of Finance Islamabad and 4 Others, the petitioners placed orders for import of tyres of Indian origin. The consignments

$5^{8} \quad$ Asian Yearbook of International Law, Vol. 10 (2001-2001), p. 207.

59 Asian Yearbook of International Law, Vol. 11 (2003-2004).

6o Asian Yearbook of International Law, Vol. 24 (2018), p. 398. 
were imported for use in Afghanistan and were notified as goods in transit. The petitioners claimed that the Customs Authorities at Karachi refused clearance of the said consignments on the basis of a letter received at the Customs House, which was issued to give effect to an earlier letter containing an order to stop smuggling back to Pakistan of tyers going to Afghanistan in transit. The Court allowed the petition, however the government of Pakistan filed petition for appeal before the Supreme Court. The Supreme Court held that the High Court had neither examined the merits of the case in light of the Custom Act nor considered the effect of the Pakistan-Afghanistan Transit Trade Agreement. The order of the High Court was set aside and the case was remanded. ${ }^{61}$ The High Court, then examined whether there was any mandate of international law, whether international law was drawn into the domestic law without the aid of a municipal law, and whether so drawn, it overrode municipal law in case of conflict. The Court held that rules of international law were incorporated into national law and considered to be part of the national law unless they are in conflict with an Act of Parliament. It further found that the Courts were under an obligation within the legitimate limits so to interpret the municipal laws as to avoid confrontation with international comity or well-established principles of international law. If conflict is inevitable, the Court noted that the latter must yield. ${ }^{62}$

In Vol. 11, Pakistan's Second Periodic Report to the Committee on the Rights of the Child submitted in April 2003 was covered. The Committee particularly noted the following developments: Pakistan's withdrawal (on 23 July 1997) of the general reservation to the Convention, Pakistan's ratification of the ILO No. 182 on the Worst Forms of Child Labour Convention 2001 (No. 182), the formulation of a revised National Plan of Action and of the Code of Ethics for Media on Reporting of Children's Issues, the adoption in 2002 of the Ordinance for the Prevention and Control of Human Trafficking and the Protection of Breastfeeding and Child Nutrition Ordinance, the Juvenile Justice System Ordinance in 2000, and the 1995 Compulsory Primary Education Act. ${ }^{63}$

\subsection{The Philippines}

A considerable number of court cases were covered in the Philippines' section. The first report on the Philippines' state practice was the Supreme Court's decision on February 26, 1990, which was featured in Vol. 1. In U.S v. Guinto, the Supreme Court ruled that the doctrine of state immunity was not absolute

61 Asian Yearbook of International Law, Vol. 3 (1993), pp. 206-208.

62 Id. at 206-208.

63 Asian Yearbook of International Law, Vol. 11 (2003-2004), p. 206. 
that no plea of immunity could be availed of by U.S. Air Force officers in relation to the bidding of contracts for the operation of barbershops inside the U.S. Armed Forces nor were the facilities demandable as a matter of right by American servicemen. ${ }^{64}$

In this volume, the issue of termination of treaties with the German Democratic Republic (GDR) was also noted due to the German Unification in 199o. The German Democratic Republic proposed the termination of a trade agreement with the Republic of the Philippines in 1977 by invoking Article 62 of the Vienna Convention on the Law of Treaties on fundamental change of circumstances as a ground for treaty termination. The Secretary, in its opinion No. 196, conceded to the application of Article 62 and dissolution of the GDR constituted a fundamental change as contemplated in Article $62 .{ }^{65}$

In 1993, the Supreme Court examined the issue of immunity of international organization in Southeast Asian Fisheries Development Center-Aquaculture Department (SEAFDEC-AQD) v. National Labour Relations Commission (NLRC) and rendered its judgment on February 14, 1992. A Research Associate at SEADEC-AQD filed a complaint for non-payment of separation. SEAFDEC-AQE was the Aquaculture Department of an international organization called the Southeast Asian Fisheries Development Centre, which was organized by the governments of Malaysia, Singapore, Thailand, Vietnam, Indonesia and the Philippines in 1967. SEAFDEC argued that the NLRC had nojurisdiction over this case as SEAFDEC was an international organization which was entitled to immunity. While the Labor Arbitration dismissed the claims by SEAFDEC, the Supreme Court reversed the ruling by saying that SEAFDEC enjoys functional independence as an intergovernmental organization, as well as freedom from control of state on whose territory its office is located. ${ }^{66}$

The Supreme Court's decision on March 1, 1993 in U.S v. Reyes concerned the issue of state immunity. A suit was instituted against the Activity Exchange manager of the US Navy Exchange at the Joint United States Military Assistance Group (JUSMAG) in Quezon City, Philippines for discriminatory and oppressive acts committed by said manager beyond the scope of her authority. The Supreme court held that an exception to the doctrine of state immunity was applicable to this case and found that immunity cannot be invoked where the public official was sued in private and personal capacity. The Court held that this rule should be extended to the agents and officials of the United States Armed Forces stationed in the Philippines. Accordingly, the Court ruled that

64 Asian Yearbook of International Law, Vol. 1 (1991), p. 168.

65 Id.

66 Asian Yearbook of International Law, Vol. 3 (1993), p. 213. 
the defendant was not entitled to immunity from civil liability for personal acts beyond the scope of official functions. ${ }^{67}$

Another immunity case was presented in Vol. 8 through the Supreme Court's case decided on September 18, 1996 in Department of Foreign Affairs v. National Labor Relations Commission. In this case, the Asian Development Bank (ADB) was sued by an employee for illegal dismissal as well as violation of the labor-only contracting law. The Supreme Court held the ADB was entitled to immunity from legal process under the Agreement Establishing the Asian Development Bank as well as under the Headquarter Agreement with the Government of the Philippines. ${ }^{68}$

In 2000, extradition case was decided by the Supreme Court on October 17, 2000 in Secretary of Justice v. Hon. Ralph C. Lantion and Mark B. Jimenez. The Supreme Court overturned its previous ruling and said that Jimenez was not entitled to the due process right to notice and hearing during the evaluation stage of the extradition process. The Supreme Court stated that a "court cannot alter, amend or add to a treaty by the insertion of any clause, small or great, or dispense with any of its conditions and requirements or take away any qualification, or integral part of any stipulation upon motion of equity, or general convenience, or substantial justice." The Court, referred that all treaties should be interpreted in the light of their intent, and examined the preamble of Presidential Decree 1069 to find its intent. Regarding the extradition treaty between the Philippines and the United States, the Court pointed out that such treaty was not a criminal proceeding that guaranteed the so-called Bill of Rights. Therefore, the temporary hold on the respondent's privilege of notice and hearing would not deprive him of fundamental fairness. ${ }^{69}$

The Supreme Court's decision on September 16, 2014 in Arigo v. Swift, Commander US 7 th Fleet involved the accidental grounding of the US Navy minesweeper on Tubbataha Reef Natural Park and World Heritage Site in the Sulu Sea due to navigational error. This incident resulted in damage to the coral reef in the marine protected area. The petitioners asked for compensatory damages and the Supreme Court dismissed the petition by applying the principle of state immunity. The Court commented on the US commitment to abide by the UN Convention on the Law of the Sea despite its non-ratification status and stated that non-membership of UNCLOS should not mean that the

67 Asian Yearbook of International Law, Vol. 4 (1993), p. 269.

68 Asian Yearbook of International Law, Vol. 8(1998-1999), p. 155.

69 Asian Yearbook of International Law, Vol. 9 (2000), p. 254. 
US could disregard the rights of the Philippines over its internal waters and territorial sea. ${ }^{70}$

\subsection{Singapore}

The state practice section for Singapore included a number of cases related to forum non-convenience under private international law as well as judicial decisions related to public international law. The first court case related to public international law was covered in Vol. 2 in Attorney General v. Elite Wood Products (Australia) Pty Ltd \& Anor, decided by the Court of Appeal on April 30, 1992. A request was made by the Ministry of Foreign Affairs in Australia to take the evidence of certain persons with addresses in Singapore for use in criminal proceedings in New South Wales. Pursuant to a notice issued by the Minister for Law, a district judge was nominated to take the evidence as requested under Article 43 of the Extradition Act. The defendants challenged the authorization of the Minister for Law, and the High Court allowed the application. As the Attorney General appealed, the Court of Appeal examined whether the Minister was authorized under the Extradition Act, and also if the Minister was duly authorized whether he exceeded his power by delegating the exercise of it to the senior district judge. In particular, the first issue involved the question of whether Australia was a foreign state for the purpose of the Extradition Act. The Court held that Australia as a declared Commonwealth country to which the Extradition Act applies, was incapable of being considered as a foreign state for the purpose of the said Act. The Court also pointed out the fact that the Minister for Law declared that Australia is a Commonwealth country for the purpose of the Extradition Act by gazette notification, which clearly indicated that Australia was recognized as a Commonwealth country rather than a foreign state. Therefore, the Court dismissed the appeal. ${ }^{71}$

In Vol. 14, the Singapore Legislature enacted a number of legislations between 2006 and 2007 to give effect to international conventions to which Singapore is a party as follows: Endangered Species (Import and Export) Act 2006 on 1 March 2006 was enacted to give effect to the enforcement obligations under the Convention on International Trade in Endangered Species of Wild Fauna and Flora; Carriage by Air Act 2007 came into force on November 16, 2007 to give effect to the provisions of the Montreal Convention, 1999. Chemical Weapons (Prohibition) (Amendment) Act 2007 came into operation on December 14, 2007, to amend the existing Chemical Weapons (Prohibition) Act which gave effect to the Convention on the Prohibition of

70 Asian Yearbook of International Law, Vol. 20 (2014), pp. 274-275.

71 Asian Yearbook of International Law, Vol. 2 (1992), pp. 176-177. 
the Development, Production, Stockpiling and Use of Chemical Weapons and on their Destruction. Geneva Conventions (Amendment) Act 2007 came into operation on 15 January 2008, to amend the existing Geneva Conventions Act to extend legal protection to the emblems of the societies included under the Geneva Convention, such as the Red Crystal and Red Lion. The Suppression of Bombings Act 2007 came into operation on January 30, 2008 to give effect to the International Convention for the Suppression of Terrorist Bombings and for matters connected therewith. Trade Marks (Amendment) Act 2007 came into operation July 2, 2007 to amend the existing Trade Marks Act to facilitate the ratification of the Singapore Treaty on the Law of Trademarks. ${ }^{72}$

In the Sahand and other applications, the High Court of Singapore examined the relationship between international law and municipal law. In this case, the defendants were subsidiaries of the Islamic Republic of Iran Shipping Lines and owners of a number of vessels including the Sahand. The Plaintiff, Societe Generale and the Export-Import Bank of Korea, issued a syndicate to the defendants for the construction of the vessels. However, the defendants defaulted and the vessels in Singapore waters were arrested by the plaintiffs in September 2010. The Court considered some key aspects of relationship between international law and domestic law in Singapore. The first aspect is related to the question of whether international law can, by itself, be an independent source of rights and obligations in Singapore. With respect to customary international law, the Court affirmed that it cannot become part of domestic law unless it has been applied or declared to be part of domestic law by a domestic court. However, regarding treaties, the Court noted that treaties have not been subject to judicial consideration in Singapore. So, in order for a treaty to be implemented in Singapore law, its provision must be enacted by the Legislature or by the Executive pursuant to authority delegated by the Legislature. ${ }^{73}$

\subsection{Sri Lanka}

Sri Lanka's state practice related to public international law first appeared in Vol. 5 with introduction of the Convention against Torture and Other Cruel, Inhuman or Degrading Treatment or Punishment Act No. 22, 1994, which gave effect to the Convention against Torture and other cruel, inhuman or degrading treatment or punishment of $1984{ }^{74}$

72 Asian Yearbook of International Law, Vol. 14 (2008), pp. 217-218.

73 Asian Yearbook of International Law, Vol. 17 (2011), pp. 266-270.

74 Asian Yearbook of International Law, Vol. 5 (1995), p. 268. 
The Supreme Court's decision on June 2, 2000 in Bulankulama and Others v. Secretary, Ministry of Industrial Development and Others, concerned the issues of international environmental law. The petitioners alleged that the proposed Mineral Investment Agreement, which was to be concluded between the Government of Sri Lanka and a foreign mining company, would result in imminent infringement of their fundamental rights as they were likely to be displaced from their homes and lands. While the main issue of the case was related to the relevant provisions under the Constitution, the potential adverse environmental impacts, argued by the petitioners, provided a strong argument for the petitioners. Therefore, the Court had an occasion to discuss precautionary principle as enunciated in the Rio Declaration and Stockholm Declarations. ${ }^{75}$

The Supreme Court considered the aspects of international human rights in Nallaratnam Singararsa v. The Attorney General and rendered a decision on September 15, 2006. The petitioner was a Sri Lankan citizen resident in Batticoloa in the Eastern Province of Sri Lanka. In 1993, while he was sleeping at home, he was arrested by Sri Lankan security forces and brought to the Komanthurai Army Camp assaulted by soldiers. The petitioner made an application to the Supreme Court for the exercise of the Court's inherent power of revision and/or review of a conviction and sentence. He argued that the position of the Sri Lanka government did not accurately represent the State's obligations under the ICCPR which requires the State to provide an effective remedy for violations of rights guaranteed by it. The Court, rather than considering the substantive issues raised by the petitioner, focused on the issue of the ICCPR and its Optional Protocol and their relevance to the Sri Lankan constitutional process. The Court considered whether Sri Lanka adopted a monist or a dualist system. Citing Articles 3 and 4 of the Constitution, the Court found that Sri Lanka followed a dualist legal system. The Court noted that while the President is empowered to conclude treaties, such treaties must be implemented by the exercise of the legislative power of parliament in order to have internal effect and attribute rights and duties to individuals. ${ }^{76}$

Some important legislations were noted in Vol. 9 and Vol. 21. In 200o, following legislations were passed: Suppression of Terrorist Bombings Act No. 11 of 1999, Mutual Assistance in Civil and Commercial Matters Act No. 39 of 200o, Prevention of Hostage Taking Act No. 41 of 2000, Suppression of Unlawful Acts Against the Safety of Maritime Navigation Act No. 42 of 2000.77

75 Asian Yearbook of International Law, Vol. 9 (2000), pp. 270-272.

76 Asian Yearbook of International Law, Vol. 13 (2007), p. 239.

77 Asian Yearbook of International Law, Vol. 9 (2000), p. 274. 
On May 15, 2015, the 19th Amendment to the 1978 Constitution of the Democratic Socialist Republic of Sri Lanka was adopted. By virtue of Article ${ }_{14} \mathrm{~A}(1)$ of the Amendment, right of access to information was incorporated into the Fundamental Rights Chapter of the Constitution. ${ }^{78}$

\subsection{Tajikistan}

Tajikistan's section on state practice first appeared in Vol. 10 with its Constitutional Court's case decided on June 12, 2001, which dealt with the issue of incorporation of certain provisions from the Criminal Procedure Code. ${ }^{79}$

In 2001, in order to implement the obligations stipulated in the Geneva Conventions on the Protection of the Victims of War of August 12, 1949 and Additional Protocols, and the Rules of using the emblems of Red Cross or Red Crescent, Tajikistan enacted the Law on the Usage and Protection of the Red Cross and Red Crescent Emblems and Appellations on May 12, 2001. This Law provided the same definition of an armed conflict, medical personnel, sanitary and transport means and emblem as provided in the Geneva Conventions and Additional Protocols. ${ }^{80}$

In order to implement the Convention on the Elimination of All Forms of Discrimination against Women, Tajikistan enacted the Law on State Guarantees of Equal Rights for Men and Women and Equal Opportunities in the Exercise of Such Rights on March 1, 2005. ${ }^{81}$

In 2006, the Law on Protection of the Objects of Historical and Cultural Heritage was enacted. This legislation was the first normative framework of its kind adopted after independence of the Tajik State in $1991 .^{82}$

Also, as part of the implementation of the Convention on the Status of Refugees of 1951, Tajikistan adopted the Law on the Status of Refugees, repealing the previous law on refugees in 1994. This law provided the definition of a refugee which is essentially the same with the definition provided in the ${ }^{1951}$ Refugee Convention except for some technical differences. ${ }^{83}$

In Vol. 11, the Supreme Court's decision made on October 2, 2003 was presented. This case involved the question of implementation of the law of terrorism by the judiciary. The Court noted that terrorism differed from other crimes that are similar in their objective characteristics. However, it held that the courts should consider that criminal cases of terrorist character as well as

\footnotetext{
78 Asian Yearbook of International Law, Vol. 21 (2015), p. 315.

79 Asian Yearbook of International Law, Vol. 10 (2001-2002), p. 240.

8o Asian Yearbook of International Law, Vol. 10 (2001-2002), p. 243.

81 Asian Yearbook of International Law, Vol. 12 (2005-2006), p. 219.

82 Asian Yearbook of International Law, Vol. 13 (2007), p. 248.

83 Asian Yearbook of International Law, Vol. 10 (2001-2002), p. 246.
} 
civil cases concerning reparations for damages caused as a result of terrorist activity may be heard. ${ }^{84}$

\subsection{Thailand}

Thailand's state practice section included a series of note and announcement related to maritime zones by the Thailand government in the 199os. In November 1992, a note was made from the government of Thailand in response to Malaysia's announcement of missile firing exercises in maritime area that intruded into Thailand's maritime zones. The Malaysian authorities expressed its apology as they made an error about the geographical coordinates of the area. ${ }^{85}$ The Office of the Prime Minister made an announcement on August 17, 1992 and February 18, 1993 concerning the straight baselines and internal waters of Thailand of June 11, 1970, and 3 areas and published such announcement in the Official Gazette. ${ }^{86}$ On August 14, 1995, Royal Proclamation establishing the Contiguous Zone was also made. ${ }^{87}$

Regarding judicial decisions, the Court of Appeal's decision on December 26, 1995 dealt with extradition case. In the Public Prosecutor v. Thanong Siriprechapond, the United States had requested the extradition of Mr. Thanong Siriprechapong, who was a former member of Parliament for the offence of narcotic drugs trafficking involving the importation into the US of multiple container loads of marijuana between 1977-1987. The Criminal Court held against the defendant on July 17, 1995 and ordered his detention pending the extradition pursuant to the Thai-US Extradition Treaty of 1983 and Thailand's Extradition Act of 1990 for the implementation of the Extradition Treaty. The defendant appealed to the Court of Appeal. The Court of Appeal found that the purpose of Thai-US Extradition treaty was to promote more effective and mutual cooperation between the two countries in the suppression of a crime. Therefore, the Court of Appeal held that good faith was a significant factor in treaty relations especially with the increase of inter-state interaction and dismissed the appeal. 88

In Vol. 11, another extradition case was reviewed by the Court of Appeal on September 30, 2003. In the Public Prosecutor v. Sok Youen a.k.a. Sok Yuen, the defendant appealed to the Court of Appeal, contending that his alleged crime of attempted murder was of a political nature and that his extradition request

\footnotetext{
84 Asian Yearbook of International Law, Vol. 11 (2003-2004), pp. 226-228.

85 Asian Yearbook of International Law, Vol. 3 (1993), p. 217.

86 Asian Yearbook of International Law, Vol. 4 (1994), p. 300.

87 Asian Yearbook of International Law, Vol. 6 (1996), p. 228.

88 Asian Yearbook of International Law, Vol. 6 (1996), pp. 228-232.
} 
was sought in order to punish him for his membership of an opposition political party in Cambodia. The Court found that even if the attempted murder of Mr. Hun Sen had been successful, that would have led to a change of the person in charge of the government, yet not of the political regime as a whole. Therefore, the Court ruled that the defendant's offence was not political in nature, rather, it was a criminal offence with the ultimate aim to cause social disturbance in the country or an act of terrorism. While the defendant also claimed to be a refugee in accordance with the $1951 \mathrm{UN}$ Convention relating to the Status of Refugees, the Court of Appeal rejected the defendant's contention as the defendant acknowledged that Thailand was not a party to the 1951 UN Convention. The Court of Appeal dismissed the appeal. ${ }^{89}$

Some notable legislations were introduced in Vol. 21 as follows: On 19 February 2015, the National Legislative Assembly of Thailand enacted the Protection for Children Born through Assisted Reproductive Technologies (ART), which significantly protected children born through ART and set the legal procedures that spouses must follow in order to have such children. The purposes of the Act were, inter alia, to specify the parent's legal status, to control boundaries on the proper use of enhanced technology, and to prohibit surrogacy involving a business or profit-making enterprise. ${ }^{90}$

On 14 May 2015, the National Legislative Assembly of Thailand voted unanimously to amend the Penal Code of Thailand to criminalize child pornography. On September 8, 2015, the Amendments to the Penal Code Act were published in the Royal Thai Government Gazette and came into effect 9o days after its publication on December 7, 2015. The Amendments defined the term 'child pornography' to meet the definition in international agreement and criminalize the acts concerning child pornography. ${ }^{91}$

\subsection{Vietnam}

Vietnam's state practice section first appeared In Vol. 5 by presenting declaration made upon ratification of the United Convention on the Law of the Sea. By this declaration, the National Assembly reaffirmed the sovereignty of Vietnam over its internal waters and territorial sea, the sovereign rights and jurisdiction in the contiguous zone, the exclusive economic zone and the continental shelf of Vietnam based on provisions of UNCLOS as well as principles of international law. ${ }^{92}$

\footnotetext{
89 Asian Yearbook of International Law, Vol. 11 (2003-2004), pp. 238-239.

$90 \quad$ Asian Yearbook of International Law, Vol. 21 (2015), pp. 321.

$91 \quad$ Id. at $322-323$.

92 Asian Yearbook of International Law, Vol. 5 (1995), p. 272.
} 
Along with this declaration, Vietnam's Law of the Sea entered into force on January 1, 2013. This Law was the country's most important and comprehensive legislation on the law of the sea. ${ }^{93}$ Other than the maritime-related legislation, in 2013, new Constitution was adopted on November 28, 2013. This new Constitution was the Vietnam's first constitution that referred to the Charter of the United Nations and embraced the pacta sunt servanda principle. ${ }^{94}$

In 2016, the Law on International Treaties was adopted and entered into force on July 1, 2016, replacing the Law on Signing, Accession, and Implementation of International Treaties of 2005. One of the significant revisions made in the new Law on International Treaties was the specification of the relationship between international treaties, the Constitution of Vietnam and other legal instruments. According to this law, the Vietnamese laws and regulations must comply with the treaties to which Vietnam is a contracting party. However, it is stipulated that the conclusion of international treaties must not be contrary to the Constitution. Therefore, according to the new Law of 2016, if there is any conflict between any legal document and a treaty to which Vietnam is a contracting party, except for Constitution, international treaty must prevail. The new Law also set the hierarchy of sources of laws as follows: (i) the Constitution, (ii) international treaties, and (iii) other legal instruments. ${ }^{95}$

\section{$2 \quad$ Conclusion}

The last 24 volumes of the Asian Yearbook of International Law over three decades covered various sources of state practices from countries in Northeast Asia, South \& Central Asia and Southeast Asia in the State Practice section. The extensive coverage of state actions and relevant documents showed a high level of Asian Countries' engagement and commitment in the international community mostly through their legislative measures to implement international treaties to which they signed or acceded. While the issues examined in judicial decisions were wide-ranging, most frequently featured court cases in the field of public international law dealt with the issues related to sovereign immunity, extradition, interpretation of international human rights law and international humanitarian law. Aside from judicial decisions related to international law, a number of cases involving interpretation of domestic laws, especially the constitutions of various Asian states provided very useful

93 Asian Yearbook of International Law, Vol. 23 (2017), p. 348.

94 Asian Yearbook of International Law, Vol. 19 (2013), p. 378.

95

Id. 
information to understand the legal development of each country. Some notable points can be made as follows:

First, since a considerable number of Asian countries featured in the Asian Yearbook of International Law were costal states, they have taken a keen interest in their maritime jurisdiction upon the adoption of the UN Convention on the Law of the Sea. Those costal states often enacted the corresponding domestic law of the sea or officially proclaimed by government's statement regarding their maritime jurisdiction with respect to internal waters, contiguous zone, and Exclusive Economic Zone.

Second, it was found that a number of domestic judicial decision involved the interpretation of international human rights treaties such as the ICCPR, Convention on the Rights of Child, Convention on the Elimination of All Forms of Discrimination Against Women, which in turn, showed the Asian countries' willingness to abide by international norms on human rights.

Third, although it was pointed out that there were relatively few cases decided by international courts or tribunals among Asian countries, it should not necessarily mean that they played a passive role in terms of dispute settlement. Rather, Asian countries opted to use diplomatic means or establish cooperation mechanism to resolve contentious issues with other countries.

The reports on state practice by 16 Asian countries for the past 30 years have proven to be an invaluable asset and will indisputably continue to shed light on the development of international law in Asia. 